\title{
Reprogramming cell fate: a scientific journey from viral enhancers to the master gene regulator Oct4 - an interview with Hans R. Schöler
}

\author{
MICHELE BOIANI* \\ Max-Planck Institute for Molecular Biomedicine, Münster, Germany
}

\begin{abstract}
As science advances, old ideas once considered dogmas are called into question by new observations that reshape our understanding of the biology and evolution of mammals. The fate of embryonic cells has long been considered as sealed, in mammals, at the stage of gastrulation, when the soma (ectoderm, mesoderm, endoderm) and the germ cells segregate from each other owing to the switching on and off of distinct gene expression programs. In this context, the term "reprogramming" means the conversion of a cell's gene expression program, from one characteristic of that cell into one characteristic of a different cell type. Programming and reprogramming rely on orchestras of genes. Dr. Schöler takes us through his scientific journey from his early attempts to clone and study developmentally important genes in viruses, to his discovery of the "master" gene Pou5f1 encoding the transcription factor Oct4. Expression of Pou5f1 marks the cells that belong to the germline - the "metagroup" of cells (including germ cells) that can pass genetic information on to the next generation. Once the germ cells have been set aside and organogenesis has taken place, Oct4 is dispensable in the soma, yet its forced expression elicits a reprogramming process that brings about a pluripotent cell state. To what extent is somatic cell reprogramming dependent on Oct4? Can cells "jump" across the germ layers without Oct4? Can reprogramming ever be perfect if cells do not pass through the germline, which is the natural way of reprogramming genomes through sexual reproduction? These and other burning questions are the topic of this interview with Dr. Schöler.
\end{abstract}

KEY WORDS: cell fate, ES cell, Oct4, pluripotency, reprogramming

Ten years ago, I thought the fate of cells was sealed in the mammalian embryo at the stage of gastrulation. The prevalent view by far was that the adult body's founder tissues, known as the "germ layers" (primitive endoderm, mesoderm, primitive ectoderm) were established in the gastrula, kept separate from the primordial germ cells (PGCs), and the progeny of a given cell would be marked and never leave its germ layer of origin. This model fit reality so well that it was almost considered as a dogma. However, even a very good fit is not always correct. In fact, in the years from 1996 to 1998, the first successful nuclear transfer experiments in both sheep and mice showed that the nuclei of adult somatic cells remembered how to make all three embryonic germ layers if transplanted into an oocyte. From the year 1999 on, evidence was mounting that cells could "transdifferentiate" from one tissue to another across germ layers, often but not always by means of fusion with local cells (Bjornson et al., 1999; Ying et al.,
2002). These reports prompted a host of questions as to the occurrence and biological significance of these unexpected observations, to the definition of the germ layers and to the identity of the genes whose expression or silencing underlay the cell fate conversion. Since then, the term "reprogramming" has been used to summarize with one word the changes occurring when one cell takes on features that it was not supposed to have. In this context, Hans Schöler has made key contributions to the molecular understanding of reprogramming. Before moving on to the interview in which I asked Hans Schöler about the said contributions,

Abbreviations used in this paper:EMBL, European Molecular Biology Laboratory; EMSA, electrophoretic mobility band shift assay; ES, embryonic stem cell; ICM, inner cell mass; ICSI, intracytoplasmic sperm injection; iPS, induced pluripotent stem cell; PGC, primordial germ cell; POU, Pit-1+Oct-1/ 2+Unc-86 family; TE, trophectoderm.

\footnotetext{
*Address correspondence to: Michele Boiani. Max-Planck Institute for Molecular Biomedicine, Röntgenstrasse 20, D-48149 Münster, Germany. Fax: +49-251-70365-399. e-mail: mboiani@mpi-muenster.mpg.de
} 


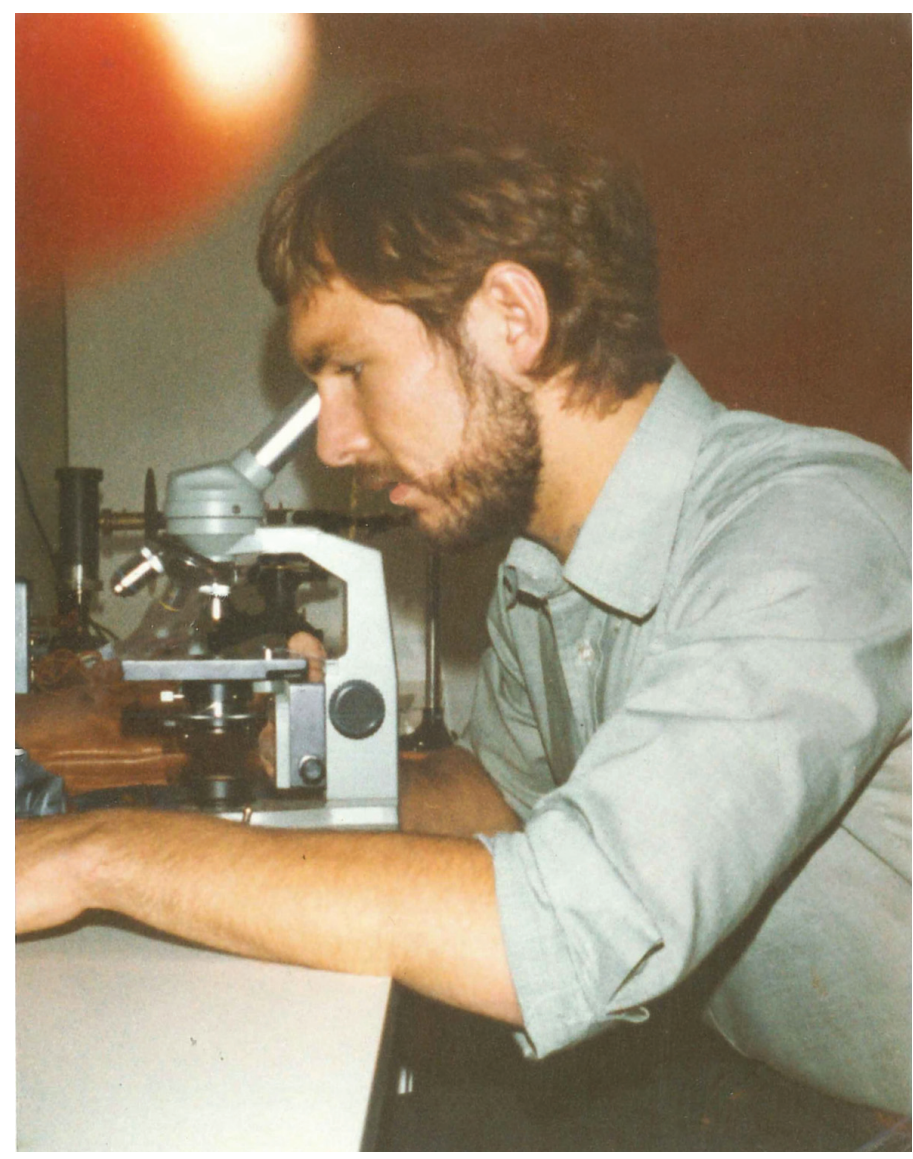

Fig. 1. Hans Schöler as a student at the Ruprecht-Karls University in Heidelberg in the late 1970s.

I first put them into context by briefly reviewing the steps in the scientific career of Hans.

Hans Schöler was born on January 30th 1953, in Toronto, Canada. He studied Biology in Heidelberg (Germany) (Fig. 1), where he received his diploma (1982) and his PhD (1985). After working in the industry at Boehringer Mannheim (now Roche) for two years, he returned to academia, joining the Max Planck Institute for Biophysical Chemistry in Göttingen (Germany). In 1991, Hans founded his own group at the European Molecular Biology Laboratory (EMBL) in Heidelberg, and during this time he achieved the "Habilitation" (1994) to later become professor. In 1999 he was appointed Professor of Reproduction Physiology at the "School of Veterinary Medicine" and Director of the "Center for Animal Transgenesis and Germ Cell Research" at the University of Pennsylvania (USA). In 2003, Hans returned to Germany, in Münster, where he now leads the Department for Cell and Developmental Biology at the local Max Planck Institute for Molecular Biomedicine, and teaches at the Westphalian Wilhelms University. These career steps span almost thirty years, during which Hans made key contributions to the molecular understanding of reprogramming. The most prominent of these was the discovery of the POU transcription factor Oct4, a protein also discovered independently also by Hiroshi Hamada in the late 1980s. Oct4 is strongly expressed in embryonic stem (ES) cells, in diploid germ cells and during oogenesis, but not in somatic cells. Oct4 is thought to be crucial for maintaining stem cell pluripotency, as well as regaining pluripotency in somatic cells. In his groundbreaking research, Hans Schöler led his group to use an Oct4 transgene to show that ES cells can be converted into mature mouse oocytes, and that forced expression of Oct4 alone can convert neural stem cells into ES-like cells called "induced pluripotent stem (iPS)" cells.

Without a doubt, scores of scientists in the field would like to get hold of Hans' brains to answer some burning questions about cell reprogramming. Well, there are certainly people more qualified than me, but I had the privilege to have Hans' brains for a couple of hours. The following interview was held in Hans Schöler's office at the Max Planck Institute for Molecular Biomedicine in Münster in May 2010. I prepared a list of questions prior to the interview with Hans, but the fact that we know each other for 12 years now led to a less formal and more lively discussion than we had planned. This is perhaps not surprising, if we consider that Hans Schöler belongs to a generation that had to invent many of its lab tools in order to answer experimental questions, whereas I came 19 years later and belong to a "spoiled" generation that uses ready-made tools purchased on Internet. On one thing we agree though: identifying the real biological questions is as important as having the tools. I hope I succeeded in grasping Hans Schöler's thoughts about cell fate and reprogramming, and in conveying them, as well as his enthusiasm, to this audience.

\section{Hans, this first question is a "must": how did you become interested in science?}

As a high school student of Gymnasium, I became fascinated with the book by Karl von Frisch, who had been studying the dance performed by bees as a directive to other bees on finding nectar. At that time, I thought about becoming an entomologist. As a young boy, I would sit in front of dunes for hours on end looking at wasps carrying their caterpillar prey to feed their progeny. And then I read the classic book from 1933, Lehrbuch der Entomologie by Hermann Weber, solidifying my initial interest in entomology, particularly, in the development of insects. My approach to entomology was rather descriptive, but after studying biology at the Ruprecht-Karls University in Heidelberg (Fig. 1), my interests shifted to molecular biology. In Heidelberg, I learnt from great teachers, such as Hermann Bujard and Peter von Sengbusch, the latter unfortunately died far too young. For example, Peter von Sengbusch always started his lectures by asking more and more difficult questions, until the students could no longer answer them; that's how he knew at what level of detail to begin teaching. And the way those teachers asked questions in the context of molecular biology was really interesting. Heidelberg was a fantastic place to do molecular biology at that time. You could say it was one of the "hot spots". After completing my university studies in Heidelberg, I worked as a biochemist, with a focus on transcription, regulation of transcription, and so forth. My keen interest in entomolgy coupled with the educational experience I received under the auspices of great teachers in molecular biology, spearheaded the development of my career as a scientist examining developmental biology at the molecular level. Well, that is how I got into science!

\section{So, you could have been an entomologist.}

Yes, certainly! From the perspective of a young boy, I could have been an entomologist, as I was always out in nature looking 
at butterflies and bugs, trying to understand their complex behavior.

You mentioned "focus on transcription, regulation of transcription". If one looks at your early papers (mid-1980s, e.g. Schöler and Gruss, 1984) they deal with enhancers, regulation of gene expression through enhancers. At the end of the 1980s, Oct4 and the other POU factors appear in your record of publications (Schöler et al., 1989a,b). Yet in the beginning you seemed to have a strong interest in enhancers. So what took you from enhancers to what would have been the focus of your research over the next 20+ years?

If you think at what was possible back then, you soon begin to realize that studying developmental biology at a molecular level was really not that easy. We didn't have the tools that we have today. The cell, not so much the organism, was the focus. This was particularly the case in the laboratory of Peter Gruss at the $\mathrm{ZMBH}$ (Zentrum für Molekulare Biologie der Universität Heidelberg), where I did my doctoral work. The door into cells was viruses. When I started my PhD, there was no direct way to get a grasp of developmentally important genes, so one would ask much simpler questions, and even those turned out to be quite difficult to answer. For instance, "How are genes in viruses regulated (viruses such as SV40, MSV)?" These types of DNA tumor viruses were studied in Heidelberg. The way to study developmental processes in the Gruss laboratory and other labs at that time was by using embryonal carcinoma cells, simply called EC cells, but studying gene regulation at the molecular level was only possible with viruses. Several years later, actually after I had returned from industry - I was at Boehringer-Mannheim, now Roche, in Tutzing for two years - to Göttingen, where Peter Gruss had since moved his department (Max Planck Institute for Biophysical Chemistry), the tools to clone and study developmentally important genes had advanced significantly.

Is it fair to say that in the beginning you were interested in general mechanisms of gene expression regulation, general principles?

Yes, it is. The question was, "How is a gene regulated, based on which elements?" At that time, we knew from viral work that genes had regulatory elements such as enhancers, promoters, and so forth. The first enhancer had been defined for a virus and it was kind of a big deal when in 1983 the groups of Walter Schaffner, Susumu Tonegawa and David Baltimore independently showed the existence of an enhancer for a non-viral gene, the heavy chain immunoglobulin gene. Schaffner, Tonegawa, and Baltimore postulated that if a virus had these regulatory elements, the enhancers, then a cell must have them as well. In three Cell papers, the above-mentioned groups were defining the first enhancer of cells, not viruses (Banerji et al., 1983; Gillies et al., 1983; Queen \& Baltimore, 1983). So 1983 was a turning point in the pursuit of gene regulation in cells; until 1983, the scientific community knew only of viral enhancers, but in 1983, they also became aware of cellular enhancers. This achievement paved the way to study gene regulation in developmental processes. In this context, you would ask questions such as, "What causes a gene to be expressed specifically at a certain stage during the development of an organism?" At that time, almost 30 years ago, it was a simple question to ask, but a very difficult one to solve experimentally.

Then, in 1989, you started with the long series of POU-related papers (named after the founder members of the POU family of transcription factors, Pit-1, Oct-1/2 and Unc-86). As far as I know you focused on Oct4 because you had an interest in the study of the germline. There are many other POU genes such as Oct1 and Oct6, but you focused on Oct4 because it is expressed specifically in the germline and you wanted to know what makes the expression of this gene specific for the germline.

Exactly! And if you read the two papers I published after

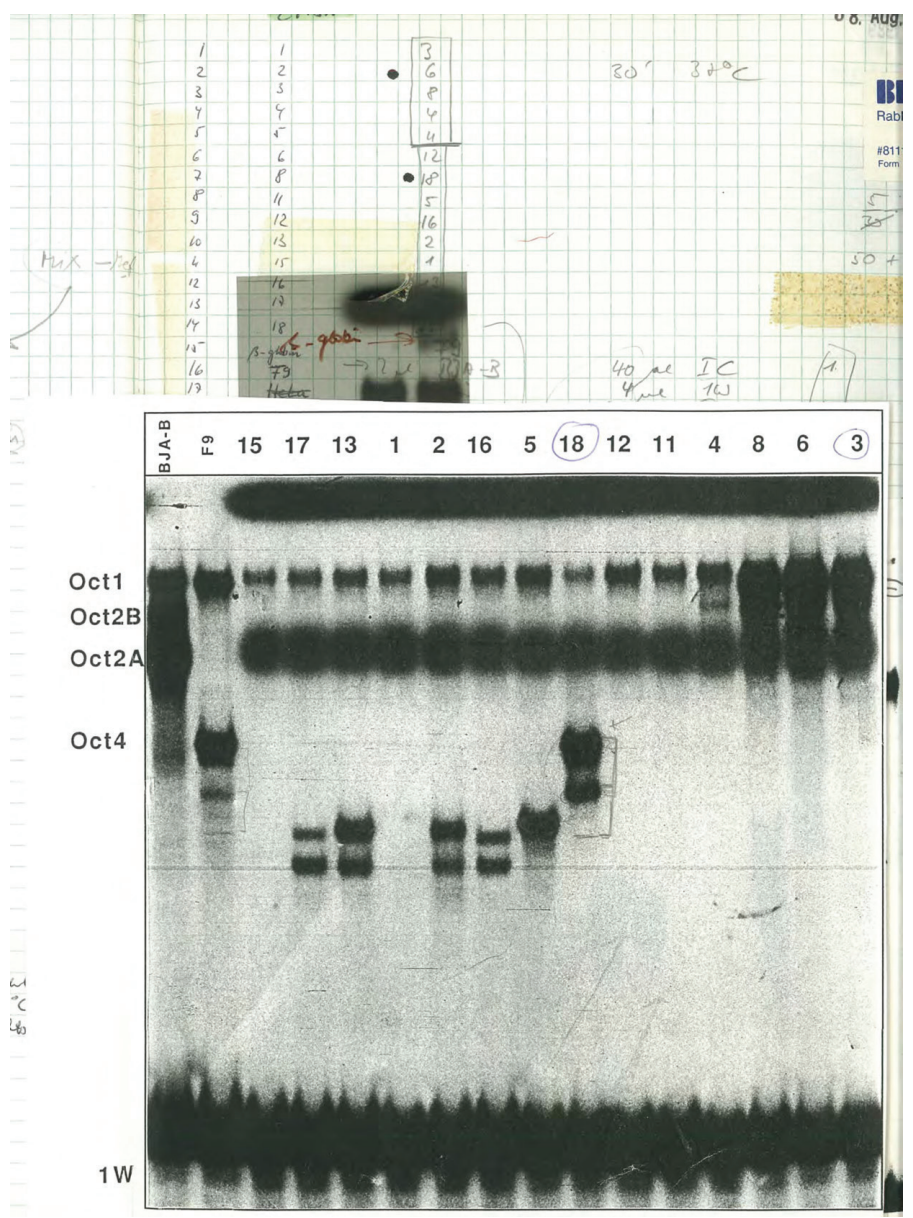

Fig. 2. A page from the 1989 lab book of Hans Schöler. This page shows evidence of the full coding sequence of Oct4 as revealed by EMSA (electrophoretic mobility band shift assay). The cloned cDNAs were first cut in the linker region 3-prime of the cDNA. With T7 RNA Polymerase RNA was then synthesized. The RNA was then incubated with a reticulocyte lysate in the presence of heavy methionine. After translation, the extract was incubated with heavy-labeled plasmid $1 \mathrm{~W}$ (the monomeric version of the $6 \mathrm{~W}$ plasmid described in the main text). Clones 17, 13, 2, 16,5 and 18 produced double bands, but only clone 18 produced bands running at the same position as the two bands of the extract of F9 embryonal carcinoma cells. This meant that the cloned and the natural product of Oct4 were of the same size, indicating that the full Oct4 coding sequence had successfully been cloned. 


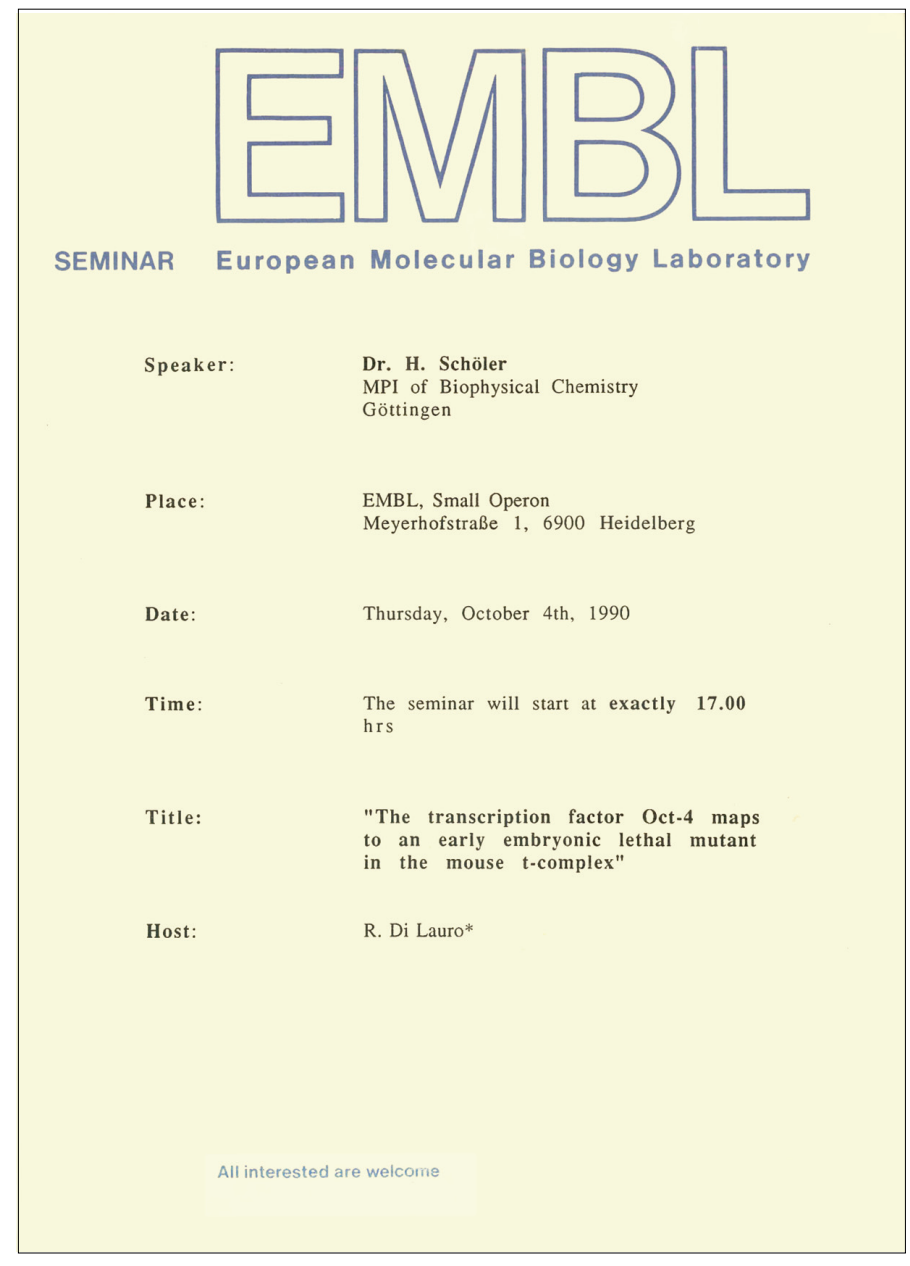

Fig. 3. Flyer announcing the invited talk given by Hans Schöler on the Oct4 gene at the EMBL (Heidelberg) in 1990.

returning from Boehringer-Mannheim, you see that I was actually looking for elements that are specifically active in the germline (Schöler et al., 1989 a,b). The doors into the germline at that time were embryonic stem cells, simply known as ES cells, EC cells, preimplantation embryos, and primordial germ cells, or simply PGCs, and, of course, oocytes and sperm. I was testing putative regulatory elements to see whether they could bind to "germline activities" in a bandshift assay (Fig. 2). It was a minimalistic way of looking at things, but it was the best I could do at that time. In a way, I was lucky that I used one particular regulatory element, the octamer motif, which I knew from the proteins of the Oct1 and Oct2 genes, which contain a homeodomain. I thought that if two factors with a homeodomain could bind to the octamer motif, then other factors should exist that can bind as well, as is the case with the Hox gene cluster. So, I took the octamer motif and passed it through different cell extracts, screening for binding activities. For this purpose, I had developed a microextraction procedure that allowed me to study a couple of hundred cells prepared in a very specific way. This micromethod even allowed me to do bandshifts with even less than 100 PGCs obtained from just one mouse fetal gonad.

Not always but often, discoveries are made possible by new advances in technology. If we think of examples, our minds may go to Ralph Brinster (see Aréchaga, 1998): without the in vitroculture media "invented" by Ralph Brinster, we would probably not be able to study (human) preimplantation embryology. Brinster also developed methods to make chimeras and transgenic animals. When it comes to your work, Hans, I can think for example of these micromethods, to make it possible to analyze just a handful of blastocysts. Back in the 1980s, with a hundred or even fewer PGCs, it was remarkable to see a band on a gel, wasn't it? I can also think of the $6 \mathrm{~W}$ plasmid [a plasmid in which reporter gene expression is driven by an enhancer that contains the octamer motif repeated 6 times]. Is there anything else that you would credit as instrumental to your achievements, besides these micromethods and the $6 \mathrm{~W}$ plasmid?

Having received training in biochemistry during my diploma thesis, I thought that such a microextraction procedure combined with a sensitive detection system was a logical way to analyze DNA binding proteins. Rudi Balling at the Max-Planck-Institute for Biophysical Chemistry in Göttingen trained me on how to isolate PGCs from genital ridges. I remember sitting together with him and referring to the book by Hogan et al. "Manipulating the Mouse Embryo" as we isolated PGCs. In addition to this micromethod, the $6 \mathrm{~W}$ plasmid was also important, as you mentioned. I had obtained the oligomerized octamer motif - that is, the binding site for Oct factors had been cloned as a hexamer in tandem with Walter Schaffners' lab, and I had recloned the hexamer in front of other reporter plasmids. We injected the $6 \mathrm{~W}$-tk-lacZ construct into oocytes and saw that the activity of this transgene (which was not integrated, but still episomal) was localized predominantly to the inner cell mass, or ICM as it is called. This result suggested to us that the activity responsible for this transgene was in the ICM. I therefore repeated the experiment with a control in which the octamer motif was mutated in front of LacZ, but I could not detect any transgene activity. This result, in turn, showed us that the activity we were looking for could be localized to the ICM. At that time, we could not distinguish between Oct4, Oct1, and Oct6. In retrospect, the observed activity could have been accounted for by any one of these three factors; for example, although Oct4 expression is specific to the germline, Oct1 is also expressed in the germline. I then cloned Oct4, the cDNA of Oct4 (Fig. 2), and found by using in situ hybridization that $6 \mathrm{~W}$-tk-lacZ activity, which I had previously defined, co-localized to cells exhibiting Oct4 gene expression. This result was indeed a major accomplishment.

It is perhaps a bit simplistic to say, but one becomes more interested in a gene if there is a phenotype associated with it. That tells you that something important is going on there. But as you started working on Oct4 in the late 1980s, there was no knockout and no phenotype for Oct4. So how did you decide to commit so much of your research efforts to the Oct4 gene? Were you ever worried that this gene could be less significant i.e. its effect less dramatic than you probably were expecting or were hoping for?

At that time, already a number of other interesting genes were examined that exhibited no phenotype after being knocked out. The number has increased since then.

Yes indeed, MyoD in 1989, for example (Weintraub et al., 
1989). To me, the effect of this gene is like a preview of induced pluripotent stem cells (iPS cells; Takahashi \& Yamanaka, 2006) almost 20 years ahead of time. By overexpressing $M y o D$ in neurons and fibroblasts, they become myoblasts, and yet mice lacking MyoD can become adults. So I agree with you, there were other hot genes at the time, and with a phenotype, whereas Oct4 did not have a phenotype.

I came to work on Oct4 from the perspective of enhancers, which we talked about earlier. I habilitated Venia Legendi in Molecular Biology in 1994 with the thesis on "Untersuchungen zur Wirkungsweise transkriptioneller Enhancer" (Investigations of the mode of action of transcriptional enhancers). Among others, I made the observation that the Oct4 factor can functionally interact with the viral oncogene E1A, work that I published in 1991 in the journal Cell (Schöler et al., 1991). The fact that the Hamada group subsequently used the Oct4-E1A interaction to backdifferentiate partially differentiated EC cells (Shimazaki et al., 1993) already hinted to me that Oct4 was involved in the undifferentiated pluripotent state, even before the Oct4 knockout was done. In addition, although the back differentiation was not from a terminally differentiated cell, that work, in a way, was the first report on reprogramming cells to pluripotency. We knew at the time that Oct4 can activate transcription in differentiated cells when its DNA binding site is located close to the TATA box. However, when its DNA binding site was located far away from the TATA box, e.g. in an enhancer position downstream of the transcription unit, Oct4 could not activate transcription in differentiated cells. In order to do so, Oct4 needed additional protein(s) to help bridge the distance from the binding site to the TATA box. This is why I called such factors bridging factors. In my assays, adenoviral $\mathrm{E} 1 \mathrm{~A}$ served as such a bridging factor, and I could show that a certain ratio of Oct 4 and $E 1 A$ was needed to exert maximum activity. With a certain level of E1A, too much or too little of Oct4 resulted in lower activities. Whenever I increased the level of E1A, I also needed a higher level of Oct4 to obtain maximum activity.

\section{Was the paper from the Hamada} group written with you or independently?

Independently. Hamada was my competitor at that time (Okazawa et al., 1991). There were three labs that were publishing on Oct4 then. I was the first to describe the protein. The cloning was done by Hiroshi Hamada, Louis Staudt and myself. Hiroshi Hamada subsequently decided to concentrate on the gene Lefty.

There were multiple papers on Oct4 at about the same time, and you were the only one to follow on this lead.

Hamada was more interested in how symmetry is established during mammalian development. He first identified Lefty and then published some wonderful papers on how the left-right axis is established. Louis Staudt came originally from the B-cell field and cloned the B-cell-specific Octfactor Oct2. Due to the retraction of one his papers on Oct4, however, he decided to go back and concentrate on B-cell related questions. By the way, I should mention that both Hamada and Staudt named the gene Oct3, following Oct1 and Oct2. A year earlier, I had named it Oct4 (Fig. 3), as I had defined 10 factors binding to the octamer motif and named them Oct3 to Oct10 (following the already-known Oct1 and Oct2).

\section{You said that one of your competitors had a paper retracted.} Was that the paper on RNA interference to knock-down Oct4 in oocytes?

Yes, it was. The 1991 paper, unfortunately, turned out to be fraudulent (Rosner et al., 1991, 1992). It was published in Cell and the authors subsequently wrote a perspective in Science, titled "Oct-3 and the beginning of mammalian development" (Rosner et al., 1991). After the first author, Mitch Rosner, left the lab to move on in his career, his colleagues could not reproduce the results. They asked him to come back and repeat the experiment. As it turned out, the Oct4 mRNA interference experiment worked only when the detergent SDS was also "present", and Rosner was caught in flagranti adding the detergent to the RNA. That's why the fertilized oocytes injected with Oct4 antisense were prevented from developing further. I felt very bad for Lou Staudt, who called me to apologize for the mess created by Mitch Rosner. I think every $\mathrm{PI}$ can imagine what a nightmare it must be when a coworker fabricates the results.

\section{Did you try to reproduce the Oct4 RNA interference results in your lab?}

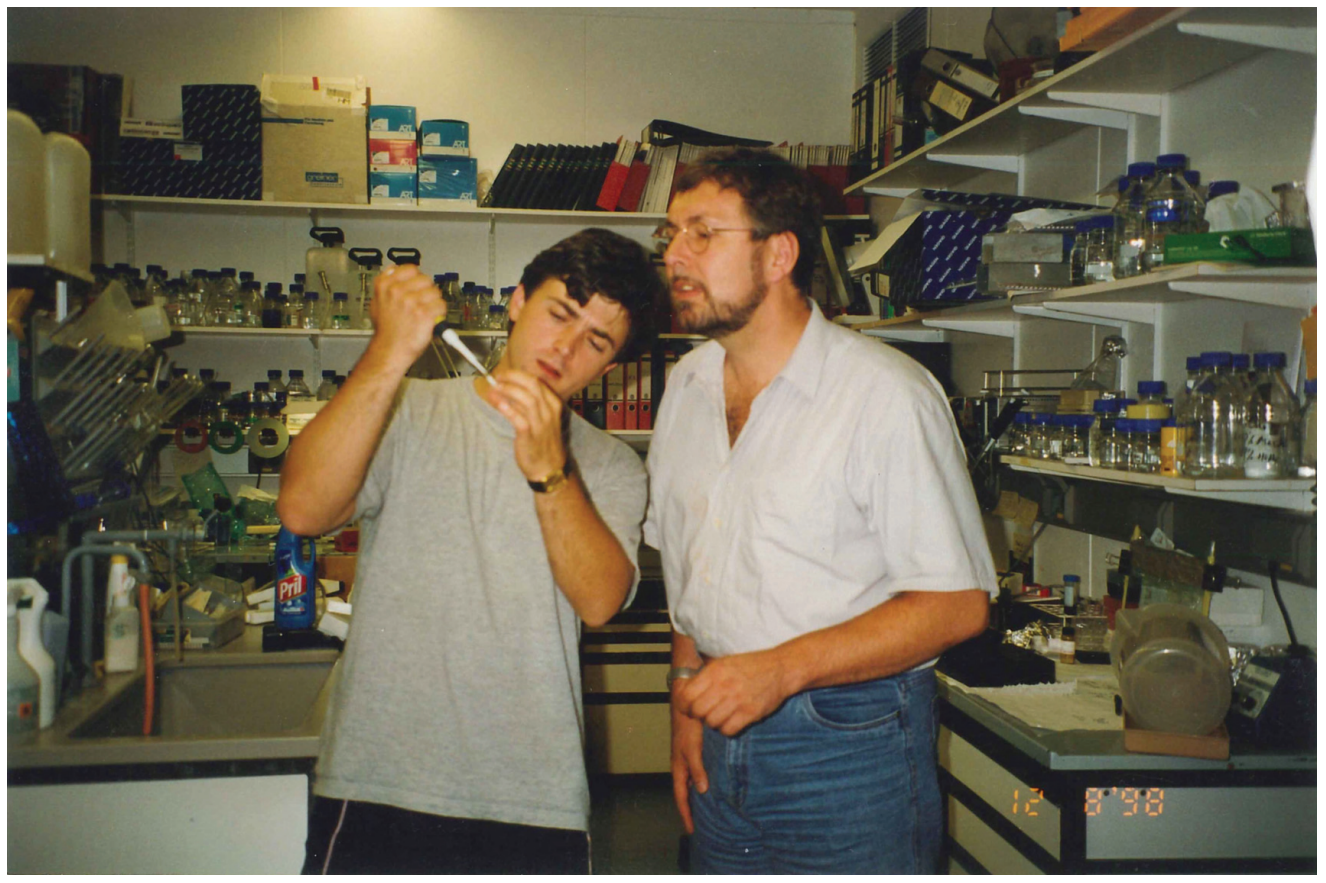

Fig. 4. Hans Schöler (right) with Alexey Tomilin (left) (1998) discussing the result of an experiment conducted at the EMBL (Heidelberg). 
Definitely! It seemed like the right experiment to do. I had just started my own lab at the European Molecular Biology Laboratory, or EMBL as it is known, in Heidelberg (Fig. 4). Incidentally, when I talked to Rosner about repeating and building on his results, he warned me that the microinjection procedure was indeed a difficult experiment to perform, requiring extremely careful purification of the oligonucleotides. In retrospect, I believe he intended to dissuade me from continuing with this work.

If I picture myself in your shoes in $1988-89$ as a young group leader with talented students, giving them projects to do, and I'm working on this gene, Oct4, which is very promising, but I don't have a phenotype (the phenotype comes in 1998; Nichols et al., 1998), where do I find the drive to keep working on this gene?

There was a host of very interesting questions about the expression pattern of Oct4, even without a knockout phenotype. Oct4 appeared to always be downregulated in cells that had abandoned the germline. Even if you were just interested in transcription, transcriptional regulation (that's where I was coming from), you would still like to know why embryonic cells switch off Oct4 as they differentiate into somatic tissues. Oct4 is a perfect tool to study questions about transcriptional regulation. A phenotype is a nice confirmation that the gene is important, but it is irrelevant if you are interested in gene regulation. Along this line of reasoning, I discovered, with Austin Cooney and Guy Fuhrmann, that Oct4 is regulated (specifically, repressed) by the Germ Cell Nuclear Factor (GCNF) in the ectodermal lineage (Fuhrmann et al., 2001). I studied with Young II Yeom and Saverio Minucci how the different Oct4 enhancers are activated. We found two different

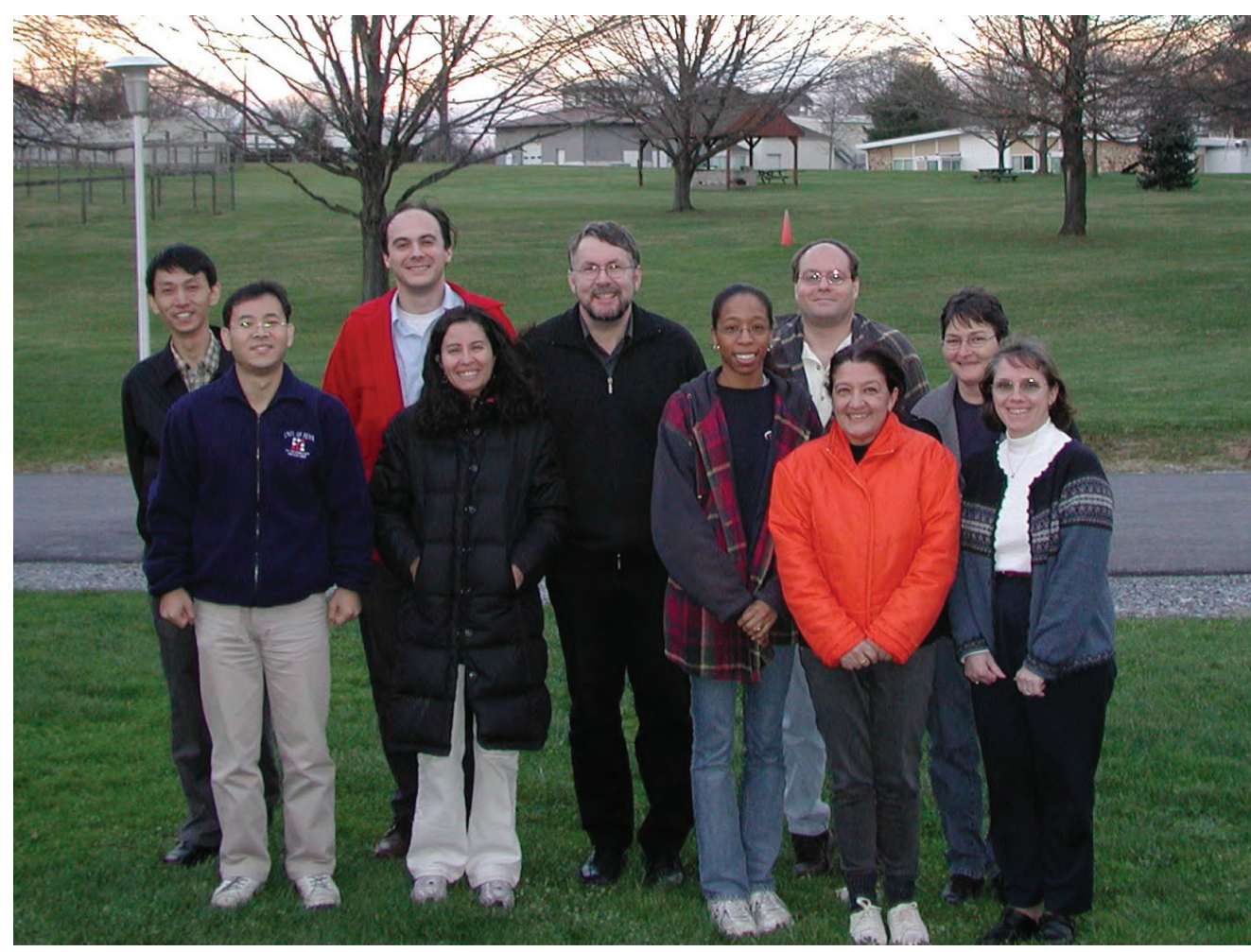

Fig. 5. Hans Schöler (center) and lab members at the Center for Animal Transgenesis and Germ Cell Research of the University of Pennsylvania (USA) in 2003. enhancers: the distal and the proximal (Minucci et al., 1996; Yeom et al., 1996). To me, this presented a perfect opportunity to study how a gene is regulated in the mammalian germline.

Now it is clear. I see why, even without a mouse phenotype, the gene Oct4 was very interesting to you, because its expression correlates with maintenance of pluripotency and germ cells. So now we move away from purely scientific questions, to more general, principle-like questions, and future perspectives. In the past, you referred in at least one of your papers to embryonic stem cells as being totipotent. The title of the paper is "Lessons of totipotency from ES cells" (Pesce et al., 1999). The now prevalent view is that they are not totipotent, but pluripotent. Maybe it is a semantic issue, but I feel that in our field, this vocabulary does have some importance. We are not just playing with words here. Now that we know ES cells are not totipotent, but pluripotent, are you redefining the meaning, or are you changing your mind on the potency of ES cells?

Also, in the Hübner et al. 2003 paper, we wrote that making oocytes out of ES cells is proof that ES cells are totipotent. You remember that was the time we were in Philadelphia, at the Center for Animal Transgenesis and Germ Cell Research at the University of Pennsylvania (Fig. 5). Countless chimera experiments spearheaded by the work of Ralph Brinster had shown that a mouse blastocyst could accept cells of a different type e.g. other than blastomeres, and that these cells could make all tissues of the mouse including germ cells. However, this was not a real experiment in the sense that not the scientist, but rather the mouse uterus was doing the trick. In the Hübner et al. (2003) paper we showed for the first time that ES cells could form oocytes entirely in vitro, thereby opening a window on the study of meiosis, which was difficult to access because it takes place in the gonads. So, what can an ES cell do? It is really important how you look at it. If you look at it from the developmental perspective, then ES cells are pluripotent - they contribute to the different lineages, but not to the trophectoderm. If you consider a cell to be totipotent that by itself can make an entire organism, then ES cells can be considered to be totipotent by the tetraploid aggregation assay. That is actually the definition found in the textbooks such as the one by Jonathan Slack, where he states that a totipotent cell is a cell that - when placed in the right enviroment - can by itself give rise to an entire organism.

So, by extension, if a cell can make an oocyte (which after fertilization is totipotent), then you argue that the same cell is also 
totipotent.

Yes, although in that context I had imagined it in a different way. At that time, we could say that all the different lineages of the adult could be made in vitro but that the germline was missing. By making oocytes, we could say that ES cells had the potential in vitro to be totipotent. But you see, in this conversation, you have to define the context. You cannot take an ES cell and put it into a uterus and make an organism. In this context, an ES cell is not totipotent, perhaps not even pluripotent. But I think there might be experimental conditions by which you can actually prove that it is totipotent. There is no twist of mind on my side, but an acceptance that at the developmental stage when you have pluripotent cells, when you have the cells that form ES cells, you also have differentiation into the lineages of the embryo proper but not into the extraembryonic lineages (pluripotency but not totipotency). In that respect, I go by the developmental perspective that the cells are pluripotent. That is what they normally do. One can force them to be totipotent, but that is not what they would normally be.

I think the tetraploid aggregation assay (Nagy et al., 1990, 1993) is a way to force them to be totipotent. You put an ES cell into this environment and if you get a mouse, then a mouse forms from just this one cell, so you can define this cell as totipotent, although this is not what pluripotent cells are normally doing. Perhaps this discussion has become obsolete, as now we can prove, in a way, that even a fibroblast under certain experimental conditions, is totipotent by the tetraploid embryo assay. But if you focus on the inability to make the extraembryonic lineages, then these cells are pluripotent. Again, it's not a twist of mind, it's just the way you're looking at it. Nevertheless, after all, these extraembryonic lineages serve the purpose of creating an interface between the fetus and the mother.

There is another assay of pluripotency, which is the teratoma assay. Historically, the original teratoma experiments of Leroy Stevens were not meant to assay pluripotency, but to pursue the stem cells of the tumor (Stevens et al., 1958). The question was different back then. By analogy to the definition of totipotency by Jonathan Slack, a cell may be defined as pluripotent if it can give rise to derivatives of the three germ layers when placed in the right environment. However, when you use the teratoma assay, you are not testing a single cell, but rather 100 thousand or a million cells. Below a certain number e.g. 1-10 thousand cells, all these cells cannot form a teratoma any more (Cao et al., 2007; Lee et al., 2009). What does it mean for pluripotency?

This would not really matter to me, as long as the 10,000 cells were clonally derived-that is, they were expanded from just one cell. Also, during development, you need a certain number of pluripotent cells to form the three germ layers. That is why the cells of the ICM need to proliferate before gastrulation can commence. In this respect, the current research is quite exciting, as there appear to be different degrees of pluripotency-one corresponding to ICM cells and another to epiblast cells.

I'm pretty sure that scientists did it in the tetraploid embryo complementation, with a single cell. Anyway, in the ICM there is room for at most three cells, as shown in a paper by Wang and Jaenisch (2004). If there is room for only three ES cells in the ICM, then it is conceivable that one cell can do it alone.
So, you put one cell into a diploid blastocyst and you make a chimera, you put one ES cell into a $4 \mathrm{~N}$ blastocyst and you make a whole mouse, albeit at very low efficiency. These assays can succeed at the single cell level.

In the experiments by Wang and Jaenisch, the somatic lineages were most often derived from one or two, and sometimes from up to three, founder ES cells. ES mice were frequently derived from only a single founder cell that was sampled from a pool of 5-15 injected cells. However, only one viable ES mouse was derived from 192 injected blastocysts, corresponding to a success rate of $0.5 \%$. Thus, ES mice can be derived from $4 \mathrm{~N}$ blastocysts that have been injected with a single ES cell, albeit, as you stated, with extremely low efficiency. This could mean a number of things. It could mean that a critical number of cells are needed for one to "succeed", for example, by forming a suitable environment. But I think the reason for these experiments was not so much to define these cells as pluripotent, but to determine the minimal number of founder cells present in the early mouse embryo. To determine whether these founder cells are pluripotent, I would be satisfied with just expanding a single ES cell into a colony, and then taking 10-15 cells from this colony and injecting them into $4 \mathrm{~N}$ blastocysts.

Yes, the environment. Kleinsmith and Pierce (1964) put a single EC cell under the mouse skin or kidney capsule, I think, or ... anyway they put one cell into a mouse, and they made teratomas with EC cells. I'm not aware that the same has been accomplished with ES cells.

I think, in principle, it is the same. Can you imagine putting a single ES cell into a defined location in a mouse? The general problem is that if you have a sample of differentiated cells, derived from ES cells, which contains even one undifferentiated cell, it may be enough to form a tumor. So, I think even a very small number of ES cells (possibly down to one ) in the right environment can form a tumor, just like a single ES cell in a blastocyst can afford high chimerism. Again, the point here is that pluripotent cells first need to proliferate and reach a critical cell number before they can form a teratoma. In my opinion, all the different lineages comprising a teratoma could not be established if only one cell were to just differentiate.

Is the level of information offered by a teratoma sufficient for you?

No. Developmental assays are much stronger. But if a teratoma forms, then you have one level of confidence that you are dealing with pluripotency, provided it is a real teratoma with various ectodermal, mesodermal, and endodermal lineages.

There are about $\mathbf{2 0 0}$ different cell types and I looked up how many tissues have been identified in teratomas. From a survey of the literature I came up with a number of around 10 15.

Right. This is why teratoma formation gives you a level of confidence. If you have a teratoma, it could be composed of say 7,10 or 15 different tissues, but as long as you find derivatives of endoderm, mesoderm, and ectoderm among these tissues, I think this test is going in the right direction. If you look into the composition of a chimera, you can't really prove that all 200 different cell types are present. Only by doing tetraploid embryo 
aggregation you can be sure. I consider tetraploid embryo aggregation as the golden proof, the real proof of pluripotency, as the live organism can only exist if all tissues are present. But in a teratoma, the presence of multiple tissues is nothing more than a hint to pluripotency. I participated in a congress on Planarians $\left(1^{\text {st }}\right.$ International Meeting on Planarian Biology, May $25^{\text {th }}-28^{\text {th }} 2010$, Münster, Germany), and scientists in that field claimed that planarians have neoblasts that are pluripotent. But if they are pluripotent cells, then why does an adult flatworm not form teratomas? Perhaps it is because the adult body provides an environment that is favorable to maintaining pluripotent cells but unfavorable for their differentiation. It would be interesting to see if the early mouse embryo and the flatworm have features in common that ensure proliferation but not differentiation of the respective pluripotent cells. Having said this, I think it still has to be unequivocally proven that the planarian cells are indeed pluripotent. For example, so far, it was impossible to perform a clonal analysis.

\section{Maybe planarians just don't live long enough to form terato-} mas ...

They live forever, in a sense. I think that neoblasts are all potential germ cells that can also become cells of somatic lineages. There is no separation of soma and germline, even in the adult. There are three germ layers, but neoblasts have the potential to differentiate into any cell type, depending on the signals they receive from the external environment. The question is, "What prevents these cells from forming teratomas?". If we were to inject pluripotent cells into our bodies, we would have a major problem, as teratomas would form.

Let us move away from assays of pluripotency and go back to development and maintenance of pluripotency. At the present time it is hard to imagine further advances in the field, after the induced pluripotent stem (iPS) cells of Takahashi and Yamanaka (2006). What do you think is going to be the next major advance or breakthrough?

I think we already got a glimpse of what the future holds from the results of the Wernig lab, namely the direct conversion of fibroblasts into neurons (Vierbuchen et al., 2010). I think the next step will be the conversion of fibroblasts into somatic stem cells, for example, neural stem cells. Obtaining neurons is great, but getting fibroblasts converted into neural stem cells would be even better. As these are adult stem cells, teratoma formation would not be an issue. If you reprogram a cell first into an iPS cell and then into a somatic stem cell, you always run the risk of forming a teratoma. But if you can show the direct programming of a somatic cell into a somatic stem cell, you can really think about in vivo reprogramming. I think we will see this happen in the next five years.

Just to give it a name, this is the concept of "transdifferentiation" that was popular in the years 20002001.

Actually, it is now popular again. Just have a look at Okada's book "Transdifferentiation. Flexibility in Cell Differentiation" from 1991. In any case, what I'm interested in, in this context, is changing cell fate from one germ layer to another and, even more, from somatic lineages to the germline lineage.
If you can jump over the germ layers, then it becomes a question of whether they really exist as well-defined entities. I came across an old paper by Jane Oppenheimer (1940), in which she argued against germ layers. Are they a theoretical construction to simplify things in our brains, or do germ layers really exist?

It is a question of how you make the cells jump. If you force a certain program onto them, say by providing certain transcription factors, it's not just an issue of the cells jumping, but rather of them being kicked. That is, you force them by using a set of transcription factors. This doesn't argue against germ layers. I think germ layers are well-defined.

Germ layers are defined by position. During gastrulation there is a primitive endoderm, and what lands on top of it becomes mesoderm. By changing the position you can change the fate of these cells, in early developmental stages. So it is a conditional if not a loose definition.

Of course, there is plasticity as long as the cells are not committed. But there is a certain point when they become committed, and my hypothesis is: as long as Oct4 is around, the cells' plasticity will enable them to enter the germline. Take, for example, the epiblast. We know that only the proximal epiblast is the region that contributes to the germline. Patrick Tam showed that if you take cells from the distal epiblast and place them in the proximal position, they will re-enter the germline (Tam and Zhou, 1996). So what I'm saying is that as long as Oct4 is active (and, as you know, it is even expressed in the initial paraxial mesoderm), this affords cells with the option of returning to the germline. Once they have entered the germline, they have the potential to exhibit pluripotency.

So, what would you expect from adult somatic cells lacking Oct4? I think of the Lengner paper (2007). Could those cells still make the jump across the germ layers?

If cells don't have the locus, there is no way they can form pluripotent cells, for example, iPS cells. But it is different to jump from a fibroblast to a neuron in the absence of the Oct4 locus. Therefore, an interesting experiment to do would be to test whether transdifferentiation is Oct4-dependent.

Oct4 is one of the members of the POU family. I was always bugged by the thought that since Oct4 does not work on its own, but as dimer or even heterodimer (Reményi et al., 2003), the ubiquitous Oct 1 could compensate for a lack of Oct4.

I think that the Oct4 protein, with its POU-specific domain and POU homeodomain, has properties of an interface. The interface is different for Oct1 and Oct4. There are other factors that bind to the interface as well. So, even if Oct1 could bind to DNA in place of Oct4, it would also have to interact with other molecules through those parts of its molecule that are not bound to DNA. It would be interesting to determine the gene expression profile when Oct4 is knocked out but Oct1 is not-this is difficult to accomplish experimentally, as ES cells differentiate in the absence of Oct4. Collaborative experiments betweeen my laboratory and that of of Patrick Matthias (Friedrich Miescher Institute, Basel) show that if either Oct4 or Oct1 is removed, embryos reach the timepoint when the first two lineages (ICM, TE) arise. But if you knock out Oct1, the TE appears to be dysfunctional (Sebastiano et al., 2010). If you 
knock out Oct4, you have an ICM problem. So, Oct4 and Oct1 can compensate for each other up to the time of lineage segregation, but this is not an option afterwards.

Back to the direct conversion of somatic cells into somatic stem cells (Vierbuchen et al., 2010), let me ask you, is the field of reprogramming and that of regenerative medicine going away from pluripotency? If you can achieve direct conversion of one lineage into another, then do you still need ES cells?

The key question now is, "How much "memory" have the neurons that Vierbuchen and Wernig generated?". In other words, "How much fibroblast character do they still have?". Vierbuchen and colleagues have shown convincingly, by several good assays, that the fibroblasts acquired features of neurons. In fact, most of the Vierbuchen paper is about testing the capability of these generated cells. Still, in terms of keeping long-term functionality, it is important to show that these neurons do not fall back to a fibroblast-like state for some reason, as they have retained this memory. This question is even more relevant, as neurons do not divide. In oocytemediated reprogramming, reprogramming is not perfect, as cloned mice become obese and die at a younger age than wild-type mice. But if you mate the two obese clones with normal mice or even with each other, you get slim offspring (Tamashiro et al., 2002). So, if you assume that even nuclear transfer does not lead to complete erasure of the epigenetic marks, then how could the erasure of epigenetic marks in a direct reprogrammig setting be better or as good as that afforded by the oocyte? If you can achieve complete erasure by direct reprogramming or transdifferentiation, you can abandon pluripotency, otherwise you can't.

Mice can live a couple of years. If we think of therapies in humans though, we have to generate reprogrammed cells that can last for decades.

That is the point. You reprogram a fibroblast into a neuron and everything looks fine, until all of a sudden, the neuron decides to divide again, as it used to do when it was a fibroblast. Therefore, to render cells suitable for therapeutic purposes, you have to ensure that the reprogramming was complete. To this end, I think nuclear transfer will see a revival, as with this technique, you really go all the way back to totipotency. In that case, the cells will be reprogrammed completely, or almost completely, and will have less of a tendency to fall back.

\section{But this comes with a string attached, the teratoma.}

I think teratoma formation is a technical problem that will be overcome in the future. For example, pluripotent stem cells could be turned into somatic stem cells that do not carry the risk for teratoma formation. For example, the neural stem cells that we keep in the lab as a cell line derived from pluripotent stem cells have no pluripotency - that is, you can inject as many neural stem cells as you would like into a mouse and you don't get teratoma formation. Of course, the question here again is: what happens after several years?

Do you think that reprogramming by fusion will have a revival too?

Not for therapeutic purposes, but the resultant tetraploid cells are useful for studying the basic principles. You bring two different worlds together easily by cell fusion, and then you ask what this clash is doing to the two genetic programs. The groups of Helen Blau (Yamanaka and Blau, 2010) and Amanda Fisher (Terranova et al., 2006) are doing wonderful work in reprogramming by fusion, providing many examples of interesting results generated by cell fusion-mediated reprogramming.

Do you think fusion is the means whereby cells are reprogrammed in vivo? Actually, do you think cells are at all reprogrammed in vivo, or is reprogramming just an experimental artifact?

If you look at the data from the Blau lab showing Purkinje cells in brain after fusion (Weimann et al., 2003), you are tempted to say "yes, cells are reprogrammed in vivo". However, I'm not sure about the physiologic relevance of the fusion process in vivo.

Maybe there is a function for cell fusion in vivo. Could it be a mechanism for response to injury (Johansson et al., 2008)?

In principle, yes, if we talk about non-dividing cells whose function is crucial, such as Purkinje neurons. However, I'm still puzzled. If a cell has been "poisoned", I still don't see how another cell could revert the damage after fusing with it. The damage in each and every case would have to be examined and specified, but still, I remain skeptical of fusion-mediated cell repair.

\section{Still, I don't think it is totally unreasonable. I'm not convinced} that cell fusion in vivo is always a mere accident.

Yes, but these processes appear to come into action when the body is relatively old. We already live much longer than expected by evolution. Unlike other species, we have removed many evolutionary restrictions. Biologically speaking, our job is over when we have passed our genetic information to the next generation. So let's not talk about fusion in someone who is 80 years old, as we are not supposed to reach 80 . Let's consider fusion in a 20 -year-old man or woman. Having said that, I am not aware that fusion is that frequent in a young organism.

Since we talked about the fidelity of reprogramming and epigenetic memory, and we speculated that reprogrammed fibroblasts turned into neurons could fall back (we don't know how stable they are), do you think cell reprogramming could, in principle, ever become perfect?

I think if you can't make it perfect with the oocyte, then you can't make it perfect by any other means. In fact, the observation that oocyte-mediated reprogramming gives rise to obese mice makes me think that reprogramming can't ever be perfect after all.

Yes, but I have my own concerns about those experiments, because anything that you culture in vitro will suffer epigenetic changes. I am still not sure if it is faulty epigenetic reprogramming or some side-effect of in vitro culture.

If you take Sertoli cells as the nucleus donors, the cloned mice have not been described as being obese.

They are not getting obese within the time frame that has been studied (Tamashiro et al., 2002), but they suffer other problems (Ogonuki et al., 2002).

Yes, but if obesity were due to culture conditions, the mice would be obese. 


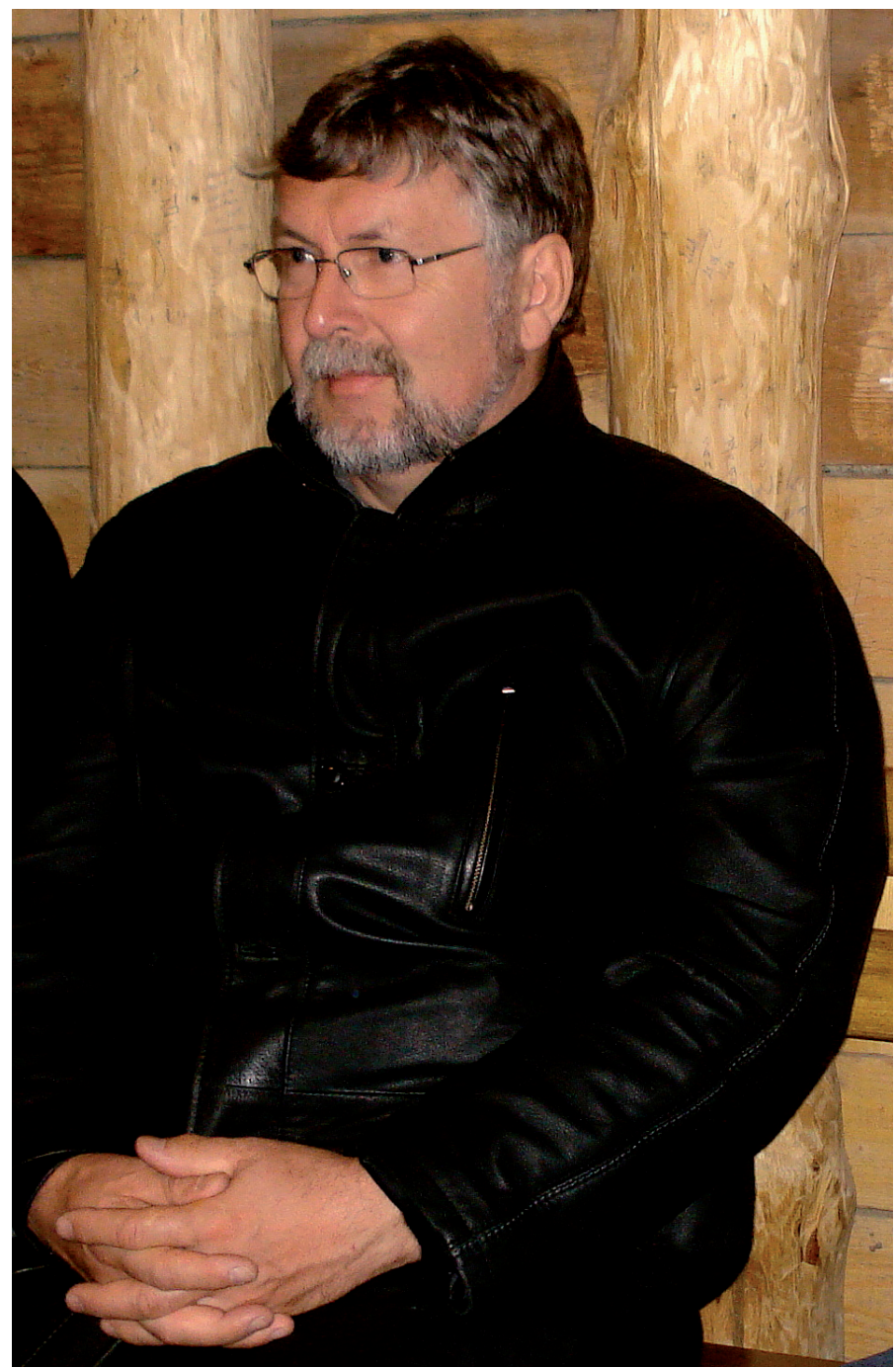

Fig. 6. Hans Schöler (2010) during a moment of relax (picture taken by Vlado Bicanski).

I'm still not sure. When I perform ICSI in mouse oocytes, i.e. something that has nothing to do with somatic reprogramming, I often see that the offspring are overweight and have larger placentae. Back to the question, do you think reprogramming actually happens in vivo or is it an in vitro artifact?

It certainly happens in vivo - reprogramming of sperm DNA happens all the time. In this context, we would not exist without reprogramming. However, I just don't know the relevance of reprogramming in the homeostasis of an organism. What could be the physiologic relevance of reprogramming in a young organism? Are there certain diseases where we could benefit from reprogramming? Fusion could become relevant as we get older, but I don't see the evolutionary pressure of establishing caveats for an older age, as we are not supposed to live to a ripe old age. But maybe you have to fuse two cells to turn on a program that is something of a novelty - maybe this is important for the liver, for example, where you have tetraploid and polyploid cells. I think future work will help us gain deeper insights into reprogramming, potentially elucidating the impact of various methods of reprogramming on cell fate both in vitro and in vivo.
Well, Hans, your secretary is making me some signs at me with her hand and I don't think she's just waving. I guess we've been talking for over two hours now and I should not be too selfish; I understand other committments are waiting for you. I just take a couple more minutes to thank the editor of The International Journal of Developmental Biology, Juan Aréchaga, for his unwavering support of this Special Issue and for encouraging me to have this open conversation with you. Without the excuse for an "interview" I don't think I could have been so brave to come and ask you so many questions, as I just did. But I think you, Hans, enjoyed these two hours too, if nothing else but because they help sharing the memory of some scientific breakthroughs and organizing ideas about them. Hans wishes all of us well and takes a well-deserved break after this interview (Fig. 6).

\section{Acknowledgements}

All members of the Schöler group, past and present, are gratefully acknowledged for contributing to the results and concepts described in this article. Special thanks to Jeanine Müller-Keuker for digging into almost 30 years of laboratory records to find the figures, and to Areti Malapetsa and Jonas Schöler for the final grammar and punctuation check.

\section{References}

ARÉCHAGA, J. Embryo culture, stem cells and experimental modification of the embryonic genome (1998). An interview with Professor Ralph Brinster. Int. J. Dev. Biol. 42: 861-878.

BANERJI, J., OLSON, L, SCHAFFNER, W. (1983). A lymphocyte-specific cellular enhancer is located downstream of the joining region in immunoglobulin heavy chain genes. Cell 33: 729-740.

BJORNSON, C.R., RIETZE, R.L., REYNOLDS, B.A., MAGLI, M.C., VESCOVI, A.L. (1999). Turning brain into blood: a hematopoietic fate adopted by adult neural stem cells in vivo. Science 283: 534-537.

CAO, F., VAN DER BOGT, K.E., SADRZADEH, A., XIE, X., SHEIKH, A.Y., WANG H., CONNOLLY, A.J., ROBBINS, R.C., WU, J.C. (2007). Spatial and temporal kinetics of teratoma formation from murine embryonic stem cell transplantation. Stem Cells Dev. 16: 883-891.

FUHRMANN, G., CHUNG, A.C., JACKSON, K.J., HUMMELKE, G., BANIAHMAD A., SUTTER, J., SYLVESTER, I., SCHÖLER, H.R., COONEY, A.J. (2001). Mouse germline restriction of Oct4 expression by germ cell nuclear factor. Dev Cell 1: 377-387.

GILLIES, S.D., MORRISON, S.L., OI, V.T., TONEGAWA, S. (1983). A tissuespecific transcription enhancer element is located in the major intron of a rearranged immunoglobulin heavy chain gene. Cell 33: 717-728.

HOGAN, B., BEDDINGTON, R., COSTANTINI, F., LACY, E. (1986). Manipulating the Mouse Embryo: A Laboratory Manual. Cold Spring Harbor Laboratory Press.

HÜBNER, K., FUHRMANN, G., CHRISTENSON, L.K., KEHLER, J., REINBOLD, R., DE LA FUENTE, R., WOOD, J., STRAUSS, J.F. 3RD, BOIANI, M., SCHÖLER, H.R. (2003). Derivation of oocytes from mouse embryonic stem cells. Science 300: 1251-1256.

JOHANSSON, C.B., YOUSSEF, S., KOLECKAR, K., HOLBROOK, C., DOYONNAS R., CORBEL, S.Y., STEINMAN, L., ROSSI, F.M.V. and BLAU, M. (2008). Extensive fusion of haematopoietic cells with Purkinje neurons in response to chronic inflammation. Nature Cell Biology 10: 575-583.

KLEINSMITH, L.J., PIERCE, G.B. (1964). Multipotentiality of single embryonal carcinoma cells. Cancer Res. 24: 1544-1551.

LEE, A.S., TANG, C., CAO, F., XIE, X., VAN DER BOGT, K., HWANG, A. CONNOLLY, A.J., ROBBINS, R.C., WU J.C. (2009). Effects of cell number on teratoma formation by human embryonic stem cells. Cell Cycle 8: 2608-2612.

LENGNER, C.J., CAMARGO, F.D., HOCHEDLINGER, K., WELSTEAD, G.G., ZAIDI, S., GOKHALE, S., SCHÖLER, H.R., TOMILIN, A., JAENISCH, R. 
(2007). Oct4 expression is not required for mouse somatic stem cell selfrenewal. Cell Stem Cell 1: 403-415.

MINUCCI, S., BOTQUIN, V., YEOM, Y.I., DEY, A., SYLVESTER, I., ZAND, D.J., OHBO, K., OZATO, K., SCHÖLER, H.R. (1996) Retinoic acid-mediated downregulation of Oct3/4 coincides with the loss of promoter occupancy in vivo. EMBO J. 15: 888-899.

NAGY, A., GÓCZA, E., DIAZ, E.M., PRIDEAUX, V.R., IVÁNYI, E., MARKKULA, M., ROSSANT, J. (1990). Embryonic stem cells alone are able to support fetal development in the mouse. Development 110: 815-821.

NAGY, A., ROSSANT, J., NAGY, R., ABRAMOW-NEWERLY, W., RODER, J.C. (1993). Derivation of completely cell culture-derived mice from early-passage embryonic stem cells. Proc Natl Acad Sci USA 90: 8424-8428.

NICHOLS, J., ZEVNIK, B., ANASTASSIADIS, K., NIWA, H., KLEWE-NEBENIUS, D., CHAMBERS, I., SCHÖLER, H.R., SMITH, A. (1998). Formation of pluripotent stem cells in the mammalian embryo depends on the POU transcription factor Oct4. Cell 95: 379-391.

OGONUKI, N., INOUE, K., YAMAMOTO, Y., NOGUCHI, Y., TANEMURA, K., SUZUKI, O., NAKAYAMA, H., DOI, K., OHTOMO, Y., SATOH, M., NISHIDA, A., OGURA, A. (2002). Early death of mice cloned from somatic cells. Nature Genetics 30: 253-254.

OKADA, T.S. Transdifferentiation: flexibility in cell differentiation Oxford: Clarendon Press; Oxford; New York: Oxford University Press, 1991.

OKAZAWA, H., OKAMOTO, K., ISHINO, F., ISHINO-KANEKO, T., TAKEDA, S., TOYODA, Y., MURAMATSU, M., HAMADA, H. (1991). The Oct3 gene, a gene for an embryonic transcription factor, is controlled by a retinoic acid repressible enhancer. EMBO J. 10: 2997-3005.

OPPENHEIMER, J.M. (1940). The non-specificity of the germ-layers. The Quarterly Review of Biology 15: 1-27.

PESCE, M., ANASTASSIADIS, K., SCHÖLER, H.R. (1999) Oct-4: Lessons of totipotency from embryonic stem cells. Cells Tissues Organs 165:144-152.

QUEEN, C., BALTIMORE, D. (1983). Immunoglobulin gene transcription is activated by downstream sequence elements. Cell 33: 741-748.

REMÉNYI, A., LINS, K., NISSEN, L.J., REINBOLD, R., SCHÖLER, H.R., WILMANNS, M. (2003). Crystal structure of a POU/HMG/DNA ternary complex suggests differential assembly of Oct4 and Sox2 on two enhancers. Genes Dev. 17: 2048-2059.

ROSNER, M.H., DE SANTO, R.J., ARNHEITER, H., STAUDT, L.M. (1991). Oct-3 is a maternal factor required for the first mouse embryonic division. Cell 64: 1103-1110.

ROSNER, M.H., DE SANTO, R.J., ARNHEITER, H., STAUDT, L.M. (1992). Retraction: Oct-3 is a maternal factor required for the first mouse embryonic division. Cell 69:724.

ROSNER, M.H., VIGANO, M.A., RIGBY, P.W., ARNHEITER, H., STAUDT, L.M. (1991). Oct-3 and the beginning of mammalian development. Science 253: 144145.

SCHÖLER, H.R., GRUSS, P. (1984). Specific interaction between enhancercontaining molecules and cellular components. Cell 36: 403-411.

SCHÖLER, H.R., HATZOPOULOS, A.K., BALLING, R., SUZUKI, N., GRUSS, P. (1989a). A family of octamer-specific proteins present during mouse embryogenesis: evidence for germline-specific expression of an Oct factor. EMBO J. 8: 2543-2550.

SCHÖLER, H.R., BALLING, R., HATZOPOULOS, A.K., SUZUKI, N., GRUSS, P. (1989b). Octamer binding proteins confer transcriptional activity in early mouse embryogenesis. EMBO J. 8: 2551-2557.
SCHÖLER, H.R., CIESIOLKA, T., GRUSS, P. (1991). A nexus between Oct-4 and E1 A: Implications for gene regulation in embryonic stem cells. Cell66: 291-304.

SEBASTIANO, V., DALVAI, M., GENTILE, L., SCHUBART, K., SUTTER, J., WU, G.M., TAPIA, N., ESCH, D., JU, J.Y., HÜBNER, K., ARAÚZO-BRAVO, M.J., SCHÖLER, H.R., CAVALERI, F., MATTHIAS, P. (2010). Oct1 regulates trophoblast development during early mouse embryogenesis. Development 137: 3551-3560.

SHIMAZAKI, T., OKAZAWA, H., FUJII, H., IKEDA, M., TAMAI, K., MCKAY, R.D., MURAMATSU, M., HAMADA, H. (1993). Hybrid cell extinction and re-expression of Oct-3 function correlates with differentiation potential. EMBO J. 12: 4489-4498.

SLACK, J.M.W. From Egg to Embryo. Regional Specification in Early Development Developmental and Cell Biology Series (No. 26). Cambridge University Press, 1st edition 1983

STEVENS, L.C. (1958). Studies on transplantable testicular teratomas of strain 129 mice. J. Natl. Cancer Inst. 20: 1257-1275.

TAKAHASHI, K., YAMANAKA, S. (2006). Induction of pluripotent stem cells from mouse embryonic and adult fibroblast cultures by defined factors. Cell 126: 663676.

TAM, P.P.L., ZHOU, S.X. (1996). The allocation of epiblast cells to ectodermal and germ-line lineages is influenced by the position of the cells in the gastrulating mouse embryo. Dev. Biol. 178: 124-132.

TAMASHIRO, K.L., WAKAYAMA, T., AKUTSU, H., YAMAZAKI, Y., LACHEY, J.L., WORTMAN, M.D., SEELEY, R.J., D'ALESSIO, D.A., WOODS, S.C., YANAGIMACHI, R., SAKAI, R.R. (2002). Cloned mice have an obese phenotype not transmitted to their offspring. Nat Med. 8: 262-267.

TERRANOVA, R., PEREIRA, C.F., DU ROURE, C., MERKENSCHLAGER, M., FISHER, A.G. (2006). Acquisition and extinction of gene expression programs are separable events in heterokaryon reprogramming. J Cell Sci. 119: 20652072.

VIERBUCHEN, T., OSTERMEIER, A., PANG, Z.P., KOKUBU, Y., SÜDHOF, T.C., WERNIG, M. (2010). Direct conversion of fibroblasts to functional neurons by defined factors. Nature 463: 1035-1041.

VON FRISCH, K. (1967). The Dance Language and Orientation of Bees. Cambridge, MA: Harvard Univ. Press.

WANG, Z, JAENISCH, R. (2004). At most three ES cells contribute to the somatic lineages of chimeric mice and of mice produced by ES-tetraploid complementation. Dev Biol. 275: 192-201.

WEBER, H. 1933. Lehrbuch der Entomologie. Verlag von Gustav Fischer, Jena, Germany.

WEIMANN, J.M., CHARLTON, C.A., BRAZELTON, T.R., HACKMAN, R.C., BLAU, H. M. (2003). Contribution of transplanted bone marrow cells to Purkinje neurons in human adult brains. Proc. Natl. Acad. Sci. USA 100: 2088-2093.

WEINTRAUB, H., TAPSCOTT, S.J., DAVIS, R.L., THAYER, M.J., ADAM, M.A., LASSAR, A.B., MILLER, A.D. (1989). Activation of muscle-specific genes in pigment, nerve, fat, liver, and fibroblast cell lines by forced expression of MyoD. Proc Natl Acad Sci USA 86: 5434-5438.

YAMANAKA, S., BLAU, H.M. (2010). Nuclear reprogramming to a pluripotent state by three approaches. Nature 465: 704-712.

YEOM, Y.I., FUHRMANN, G., OVITT, C.E., BREHM, A., OHBO, K., GROSS, M., HÜBNER, K., SCHÖLER, H.R. (1996). Germline regulatory element of Oct-4 specific for the totipotent cycle of embryonal cells. Development 122: 881-894.

YING, Q.L., NICHOLS, J., SMITH A.G. (2002). Changing potency by spontaneous fusion. Nature 416: 545-548. 


\section{Further Related Reading, published previously in the Int. J. Dev. Biol.}

See our recent Special Issue Placenta edited by Joan S. Hunt and Kent L. Thornburg at: http://www.ijdb.ehu.es/web/contents.php?vol=54\&issue=2-3

Enhancing somatic nuclear reprogramming by Oct4 gain-of-function in cloned mouse embryos Martin J. Pfeiffer, Sebastian T. Balbach, Telma C. Esteves, Nicola Crosetto and Michele Boiani Int. J. Dev. Biol. (doi: 10.1387/ijdb.103197mp)

Modulation of mitochondrial biogenesis and bioenergetic metabolism upon in vitro and in vivo differentiation of human ES and iPS cells

Alessandro Prigione and James Adjaye

Int. J. Dev. Biol. (doi: 10.1387/ijdb.103198ap)

Reprogramming of melanoma cells by embryonic microenvironments

Alejandro Díez-Torre, Ricardo Andrade, Cristina Eguizábal, Elixabete López, Jon Arluzea, Margarita Silió and Juan Aréchaga Int. J. Dev. Biol. (2009) 53: 1563-1568

Mouse induced pluripotent stem cells

Eamon Geoghegan and Lucy Byrnes

Int. J. Dev. Biol. (2008) 52: 1015-1022

Epigenetic reprogramming of the genome-from the germ line to the embryo and back again.

K L Arney, S Erhardt, R A Drewell and M A Surani

Int. J. Dev. Biol. (2001) 45: 533-540

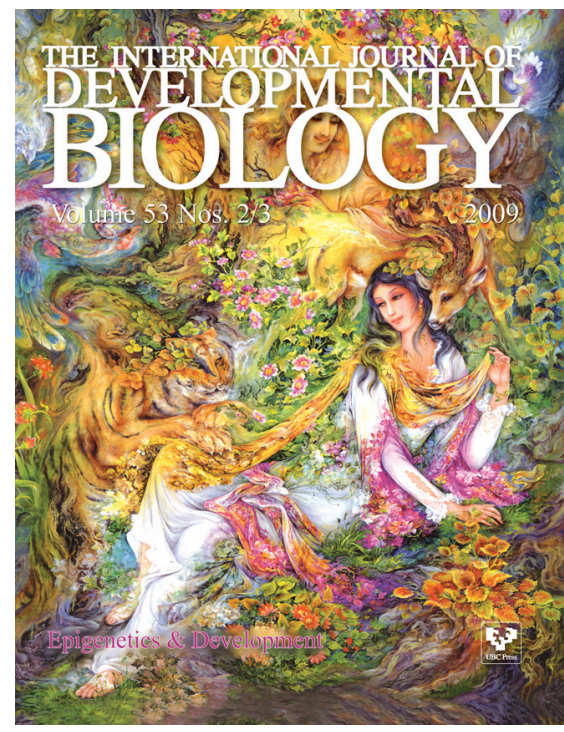

5 yr ISI Impact Factor $(2009)=3.253$

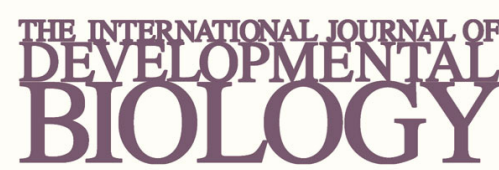

Volume 54 Nos. $6 / 7$
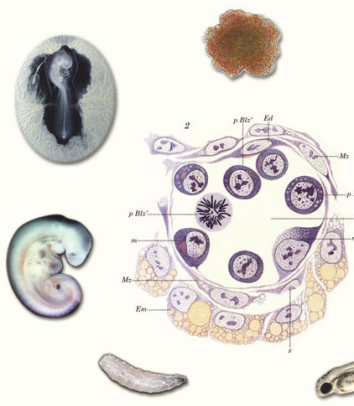

Developmental Hematopoiesis
Special Issue
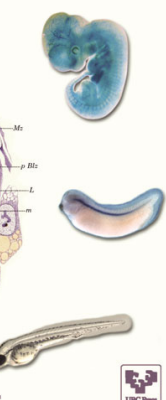

5

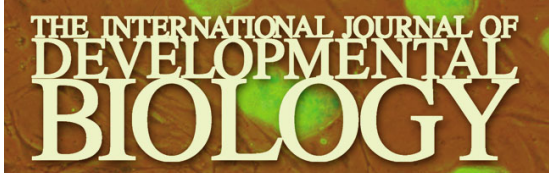

Volume 54 Nos. $11 / 12$

Special Issue

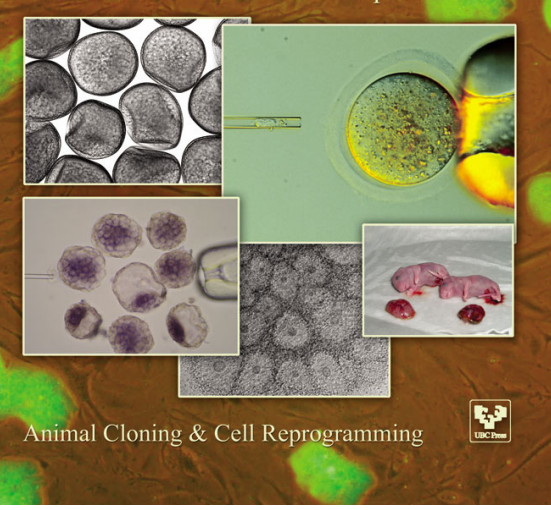

